\title{
Cikkismertetés: Mi a népegészségügy és a népegészségügyi rendszer meghatározása?
}

\author{
Article review: What are the definition of the public health and \\ the public health systems?
}

Ismertető: $\quad$ Vitrai József $₫$

Ismertetett cikk: Jarvis, T, Scott, F, El-Jardali, F, Alvarez E. Defining and classifying public health systems: a critical interpretive synthesis. Health Res Policy Sys 2020;18:68. https://doi.org/10.1186/s12961-020-00583-z

Beküldve: $\quad$ 2020. 07. 10.

doi: $\quad$ 10.24365/ef.v61i4.610

Kulcsszavak: népegészségügy; rendszerek; alapvető feladatok; alapvető szolgáltatások

Keywords: public health; systems; essential functions; essential services

\section{HÁTTÉR}

A 2000-es évek elején az egészséget meghatározó tényezők jelentőségének felismerése az egészség holisztikus értelmezése felé elmozdulást, valamint a lakosság egészségének javításában a népegészségügy szerepének fokozott elismerését hozta.

Míg számos elméleti keret létezik az egészségügyi rendszer fogalmának meghatározására, addig a népegészségügyi rendszerre vonatkozóan nem találni kielégítő definíciót.

A tanulmány célja a népegészségügyi rendszer mibenlétének megfogalmazása, valamint az egészségügyi ellátórendszer és a népegészségügyi rendszer közötti különbségek feltérképezése a mindkettőt magába foglaló egészségügyi rendszer elméleti keretein belül.

\section{MÓDSZEREK}

A tanulmány szerzői kritikus, értelmező szintézist végeztek. A keresett adatbázisok között szerepelt az EBSCOhost, az OVID, a Scholars Portal, a Science of
Web, a Cochrane Library és a Health Systems Evidence. Az adatok kinyerése, kódolása és elemzése a „legjobban illeszkedő elemzési modell” („,best fit” framework synthesis) módszert követte. A kiindulási kódolás az egészségügyi rendszerek és a szakpolitikák széles körben elfogadott osztályozására (irányítási, pénzügyi és szolgáltatási rendszer) [1. táblázat], továbbá a népegészségügy alapvető feladatainak és szolgáltatásainak rendszerére [2. táblázat] épült.

\section{EREDMÉNYEK}

Összesen 5933 egyedi dokumentumot azonosítottak, és ebből 67-et vontak be az elemzésbe. A népegészségügy és a népegészségügyi rendszer meghatározásai, valamint szerepük és feladataik jelentősen eltértek a különböző térségi, mint pl. szövetségi, állami, megyei, települési szintek között. A népegészségügyet és népegészségügyi rendszert általában az egészségügyi rendszerhez hasonlóan jellemzik, kiegészítve a partnerség (közösségi és ágazatközi) és a kommunikáció nagyobb szerepével. 
A népegészségügy - az áttekintett dokumentumok összegzése alapján - „objektív eredményeken alapuló, de a lakosság szükségleteire és helyzetére is reagáló tudomány, amelynek célja a közösség egészségi szükségleteinek kielégítése. A népegészségügy sokféle, szervezett tevékenység együttese, melynek célja az életminőség javítása, és az egészségegyenlőtlenségek csökkentése az emberek boldogulása érdekében."

A népegészségügyi rendszer meghatározása pedig: „a kormányzati, magán- és egyéb közszereplőknek a népegészségügy küldetését és alapvető feladatai teljesítését szolgáló szervezeteinek, erőforrásainak együttese. A népegészségügyi rendszer a közösség népegészségügyet támogató, az egészséget befolyásoló erőforrásainak, infrastruktúráinak és szakpolitikáinak együttese". [3. táblázat]

A szerzők felvázolják a népegészségügyi rendszer elméleti keretét, és azt, hogy a népegészségügy miként illeszthető az egészségügyi rendszerbe. [1. ábra]

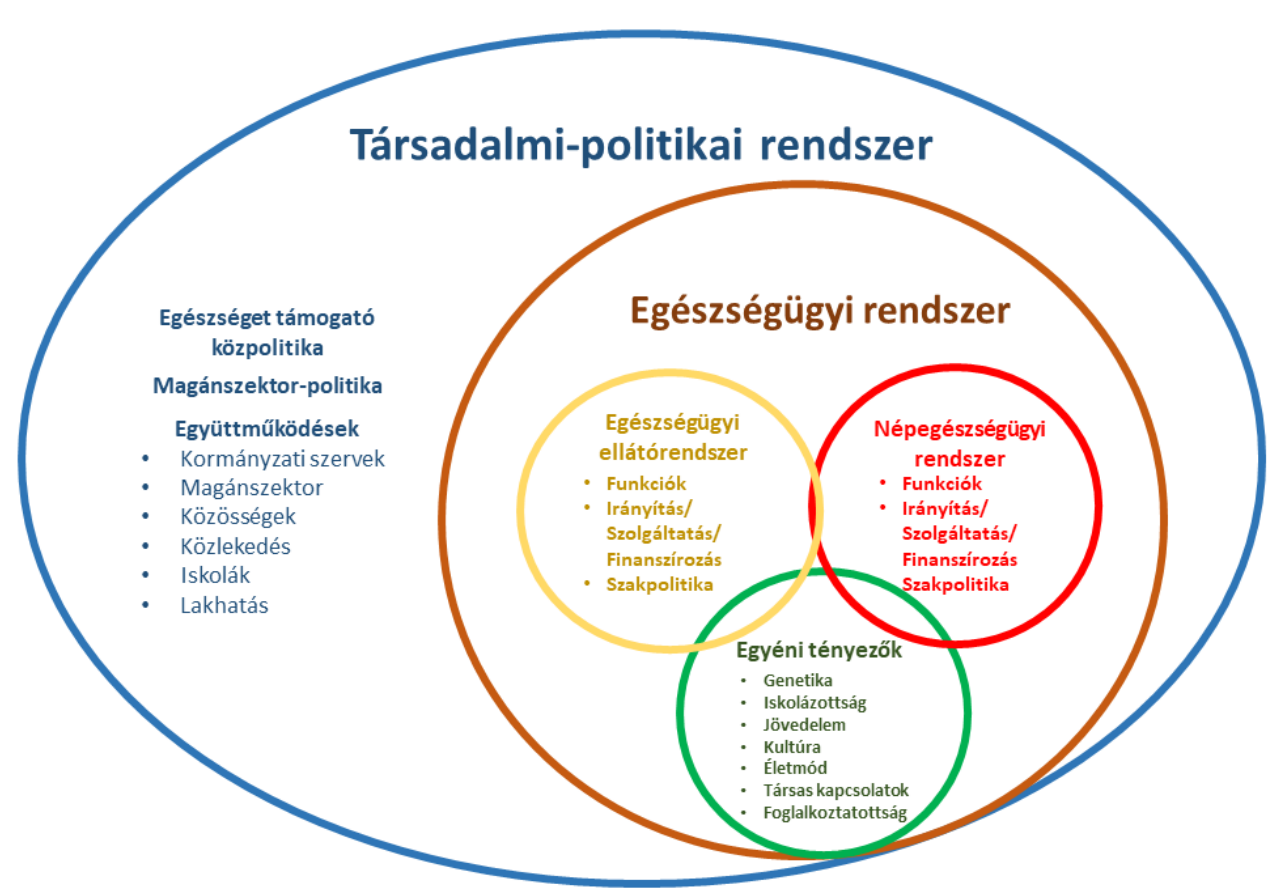

\section{KÖVETKEZTETÉSEK}

A népegészségügyi rendszer az egészségügyi rendszer egyedülálló és létfontosságú eleme. Annak vizsgálatán túl, hogy a népegészségügyet és népegészségügyi rendszert miként fogalmazták meg a szakirodalomban, ez a közlemény rámutat arra, hogy a népegészségügy feladatainak meghatározása elengedhetetlen ahhoz, hogy tisztázzuk a nagyobb egészségügyi rendszeren belül játszott szerepét, és hogy megértsük a népegészségügynek, az egészségügyi ellátásnak és a népesség egészségének egymáshoz való viszonyát. Általánosabban fogalmazva, ez a tanulmány egyrészt rámutat a népegészségügyi rendszer megértésének fontos hiányosságaira, másrészt kiegészíti a népegészségügyi rendszer elméletét és gyakorlatát, harmadrészt új kutatási témákat javasol. 


\section{TANULSÁGOK A HAZAI SZAKEMBEREK SZÁMÁRA}

A cikk ráirányítja a figyelmet arra, hogy a hazai népegészségügy megfelelő múködéséhez fontos lenne az elvégzendő feladatok pontos kijelölése, azokat megvalósító szereplők azonosítása, valamint a köztük fennálló kapcsolatok rendszerszintű tisztázása. Ehhez jól használhatók az ismertetett áttekintő közlemény összegző meghatározásai, az összegyűjtött szakirodalmi források kritikai és szintetizáló bemutatása. A cikk komoly segítséget jelenthet a hazai népegészségügyi szakemberek továbbképzéséhez is.

1. táblázat: Kiindulási szempontok a népegészségügyi rendszer meghatározásához az egészségügyi rendszer jellemzői alapján

\begin{tabular}{|c|c|c|}
\hline \multicolumn{3}{|c|}{ Legfontosabb szempontok } \\
\hline \multirow{14}{*}{$\begin{array}{l}\text { Partnerség és } \\
\text { kommunikáció }\end{array}$} & \multirow{5}{*}{ Irányítás } & Szakpolitika \\
\hline & & Szervezetfelügyelet \\
\hline & & Kereskedelemi felügyelet \\
\hline & & Szakmai felügyelet \\
\hline & & Fogyasztók és érdekeltek bevonása \\
\hline & \multirow{5}{*}{ Finanszírozás } & Finanszírozási rendszer \\
\hline & & Forrásbiztosító szervezetek \\
\hline & & Visszatérítő szervezet \\
\hline & & Eszköz- és szolgáltatásváráslás \\
\hline & & Fogyasztók ösztönzése \\
\hline & \multirow{4}{*}{ Szolgáltatás } & $\begin{array}{l}\text { Hogyan veszik figyelembe a programok, szolgáltatások tervezésekor a fogyasztók } \\
\text { szükségleteit? }\end{array}$ \\
\hline & & Ki biztosítja a programokat és a szolgáltatásokat? \\
\hline & & Hol vannak a programokat és a szolgáltatásokat? \\
\hline & & Milyen támogatás kapcsolódik a programok és szolgáltatások biztosításához? \\
\hline
\end{tabular}

2. táblázat: Szempontok a népegészségügy feladatainak csoportosításához

\begin{tabular}{|c|c|c|}
\hline \multirow{10}{*}{$\begin{array}{l}10 \text { Alapvető Népegészségügyi } \\
\text { Szolgáltatás (U.S.A.) }\end{array}$} & \multirow{2}{*}{ Értékelés } & Egészségfelmérés/-monitorozás \\
\hline & & Kivizsgálás/adatgyűjtés \\
\hline & \multirow{3}{*}{ Szakpolitika kialakítása } & Tájékoztatás-nevelés/egészségfejlesztés \\
\hline & & Partnerek bevonása /érdekvédelem \\
\hline & & Szakpolitika kidolgozása/tervezés \\
\hline & \multirow{5}{*}{ Feltételek biztosítása } & Szabályozás/ellenőrzés \\
\hline & & Egészségügyi szolgáltatás nyújtása/biztosítása \\
\hline & & Szakember-továbbképzés \\
\hline & & Szolgáltatás-értékelés \\
\hline & & Kutatás \\
\hline \multirow{8}{*}{ Múködő Alapvető Szolgáltatások } & & Járványügyi felügyelet \\
\hline & & Nem fertőző betegségek/sérülések megelőzése \\
\hline & & Egészségvédelem \\
\hline & & Vészhelyzeti tervezés/intézkedés \\
\hline & & Laboratóriumi szolgáltatások \\
\hline & & Engedélyezés \\
\hline & & Programmegvalósítás \\
\hline & & Erőforrás-/szervezetmenedzsment \\
\hline
\end{tabular}




\begin{tabular}{|c|c|c|}
\hline & Meghatározás/Leírás & Javasolt meghatározás \\
\hline \multirow{7}{*}{ 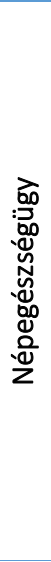 } & Az egészségfejlesztés és -védelem tudománya, a betegségek megelőzése, valamint az & \multirow{7}{*}{$\begin{array}{l}\text { A népegészségügy olyan objektív } \\
\text { eredményeken alapuló, a lakosság } \\
\text { szükségleteire és helyzetére is reagáló } \\
\text { tudomány, amelynek célja a közösség } \\
\text { egészségi szükségleteinek kielégítése. } \\
\text { A népegészségügy különféle szerve- } \\
\text { zett tevékenységek együttese, mely- } \\
\text { nek célja az életminőség javítása, és } \\
\text { az egészségegyenlőtlenségek csökken- } \\
\text { tése az emberek boldogulása érdeké- } \\
\text { ben. }\end{array}$} \\
\hline & $\begin{array}{l}\text { A társadalom szervezett erőfeszítései a betegségek és a korai halálozás megelőzésére, } \\
\text { az emberek egészségének megőrzésére, az egészség és a jóllét javítására, valamint az } \\
\text { egészségügyi egyenlőtlenségek csökkentésére. }\end{array}$ & \\
\hline & A közösség egészségének védelmére irányuló proaktív megközelítés. & \\
\hline & $\begin{array}{l}\text { A népegészségügy a társadalom kollektív érdekének megfelelően olyan környezetet biz- } \\
\text { tosít, amely lehetővé teszi az emberek boldogulását. }\end{array}$ & \\
\hline & $\begin{array}{l}\text { A tudomány alkalmazásának politikája az egészség terén mutatkozó egyenlőtlenségek } \\
\text { csökkentése és a lakosság általános egészségének biztosítása céljából. }\end{array}$ & \\
\hline & $\begin{array}{l}\text { A társadalomorvoslás más szektorok, vagyis a szociális, az oktatás döntéseinek, } \\
\text { szakpolitikáinak hatása az egészségre. }\end{array}$ & \\
\hline & $\begin{array}{l}\text { A lakosság egészségének előmozdítására és védelmére, valamint az egészségi } \\
\text { szükségletek kielégítésére összpontosító tevékenységek különféle csoportja. }\end{array}$ & \\
\hline \multirow{10}{*}{ 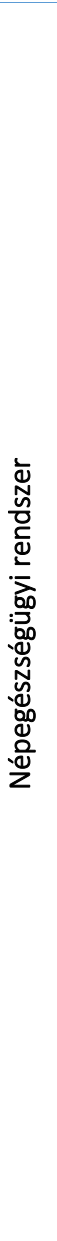 } & $\begin{array}{l}\text { Magába foglalja a kormányzati és nem kormányzati szervek minden olyan szintjét, amely } \\
\text { osztozik az egészséges környezet biztositásának felelősségében. Ez szervezetek összetett } \\
\text { hálózata, amely ellátja a népegészségügy alapvető feladatait a közösség egészségének } \\
\text { védelme és fejlesztése érdekében. }\end{array}$ & \multirow{10}{*}{$\begin{array}{l}\text { A népegészségügyi rendszer a kor- } \\
\text { mányzati, magán- és közszereplőknek } \\
\text { a népegészségügy küldetését és } \\
\text { alapvető feladatai teljesítését szolgáló } \\
\text { szervezeteinek, erőforrásainak együt- } \\
\text { tese. A népegészségügyi rendszer } \\
\text { a közösség népegészségügyet támo- } \\
\text { gató, az egészséget befolyásoló } \\
\text { erőforrásainak, infrastruktúráinak és } \\
\text { szakpolitikáinak összesége. }\end{array}$} \\
\hline & A népegészségügyi rendszer nemzeti, állami/tartományi és helyi ügynökségekból áll. & \\
\hline & $\begin{array}{l}\text { Kormányzati népegészségügyi hivatalok, amelyek más köz- és magánszervezetekkel } \\
\text { együttmúködve különböző népegészségügyi tevékenységeket folytatnak a } \\
\text { közösségben. }\end{array}$ & \\
\hline & $\begin{array}{l}\text { Kormányzati, magán- és közigazgatási ügynökségek és szervezetek, amelyek tevékeny- } \\
\text { sége hatással van a lakosság egészségére, továbbá a népegészségügyi tevékenységeket } \\
\text { támogató infrastruktúra és jogszabályok. }\end{array}$ & \\
\hline & $\begin{array}{l}\text { Kormányzati, nem kormányzati és közösségi szervezetek, amelyek a közigazgatás } \\
\text { minden szintjén múködnek, és a népegészségügyi kezdeményezések megvalósitásáért, } \\
\text { a szakpolitikai feltételek és a finanszírozás biztositásáért, valamint a programok koordi- } \\
\text { nálásáért felelősek. }\end{array}$ & \\
\hline & $\begin{array}{l}\text { A népegészségügyi rendszerek szolgáltatásokat nyújtanak a lakosság számára azzal az } \\
\text { elsődleges céllal, hogy rendeletekkel és oktatással csökkentsék a betegségeknek való ki- } \\
\text { tettséget. }\end{array}$ & \\
\hline & $\begin{array}{l}\text { Egyének és szervezetek, amelyek egy közösség vagy népesség egészségéért dolgoznak } \\
\text { általában egy kormányzati ügynökség felügyelete alatt, amely a partnerek tevékenységét } \\
\text { irányítja a rendszercélok elérése érdekében. }\end{array}$ & \\
\hline & $\begin{array}{l}\text { A népegészségügyi rendszerek helyi, regionális, nemzeti és nemzetközi szinten működ- } \\
\text { nek annak érdekében, hogy átfogó programokat nyújtsanak partnerségek és multidisz- } \\
\text { ciplináris együttmúködések, szakemberekből és érdekképviselőkből álló csoportok } \\
\text { révén a közösségek egészségének javítása és védelme érdekében. }\end{array}$ & \\
\hline & $\begin{array}{l}\text { A népegészségügyi rendszer különálló és az egészségügyi ellátórendszert erősítő elem. } \\
\text { Népegészségügyi jellege miatt a népegészségügyi rendszer alapvetően formális és infor- } \\
\text { mális népegészségügyi szervezetek és társadalmi csoportok közötti partnerségekből áll, } \\
\text { amelyek célja az egészséget meghatározó tényezők befolyásolása. }\end{array}$ & \\
\hline & $\begin{array}{l}\text { A népegészségügy alapvető építőköve, amely a közösséget és a szervezeteket partner- } \\
\text { ségeken keresztül egyesíti az alapvető népegészségügyi feladatok ellátása, valamint a } \\
\text { népegészségügyi gyakorlat és teljesítmény egységesítése érdekében. }\end{array}$ & \\
\hline
\end{tabular}

